REPORTS OF MORPHOLOGY
Official Journal of the Scientific Society of Anatomists,
Histologists, Embryologists and Topographic Anatomists
of Ukraine
journal homepage: https://morphology-journal.com

\title{
Changes in the cellular composition of guinea pig's distal airways epithelium in the dynamics of experimental ovalbumin-induced allergic inflammation
}

\section{Popko S.S.}

Zaporizhzhia State Medical University, Zaporizhzhia, Ukraine

\section{ARTICLE INFO}

Received: 21 July 2021

Accepted: 24 August 2021

UDC: $611.23 .018 .7: 616.233-056.3-$ 092.9].087.1:599.324.7

\section{CORRESPONDING AUTHOR}

e-mail: kluchkosv@gmail.com Popko S.S.

\begin{abstract}
The problem of studying the processes of restructuring of airways epithelium of humans and animals of adaptive nature under the influence of various factors on the body remains the subject of scientific discussions. The aim of this work is to study morphometric changes in the cellular composition guinea pig's distal airways epithelium in the dynamics of experimental ovalbumin-induced allergic inflammation. We studied lung of 48 male guinea pigs, using histological, morphometric and statistical methods, under conditions of experimental ovalbumin-induced allergic inflammation, simulated by subcutaneous sensitization and subsequent intranasal inhalation with ovalbumin. The average number of epithelial cells of small bronchi and terminal bronchioles was determined: basal epithelium cells, ciliated cells, goblet cells and exocrine bronchiolar cells per unit area of $10000 \mu \mathrm{m}^{2}$. We have shown the most significant reactive morphometric changes on the $23 \mathrm{rd}$ and 30 th days of the experiment. We demonstrated a decrease of the number of basal cells (by 1.5 times compared to the control, $p^{* / *}<0.01$ ) and ciliated cells (by 1.6 times compared to the control, $p^{* / *}<0.001$ ) and an elevation of the average number of goblet cells (by 2.6 times compared to the control, $\left.p^{* / *}<0.01\right)$ in bronchioles, a decrease of the average number of exocrine bronchiolar cells (by 1.6 times compared to the control, $p^{* / * *}<0.01$ ) in terminal bronchioles. These changes are the morphological confirmation of the development of bronchial hyperreactivity as a result of the action of the allergen. Sensitization and allergization with ovalbumin cause statistically significant morphological changes in the cellular composition of small bronchi and terminal bronchioles of an alterative nature in the early period and adaptive - in the late period of allergic inflammation, corresponding to the main morphological manifestations of allergic inflammation.

Keywords: epithelium, airways, allergic inflammation, ovalbumin, guinea pig.
\end{abstract}

\section{Introduction}

The condition of the respiratory epithelium is crucial for maintaining the health of the respiratory system and is a major barrier to various aeroallergens. While the development of allergic inflammation of the airways the epithelium is both a mediator and a target of inflammatory process. Its remodeling is the basis for airways obstruction $[1,2,12,14]$. In addition, recent studies indicate important immunogenic and immunomodulatory functions of airways epithelium [4, 10, 17]. In particular, a triad of cytokines, including IL-25, IL-33 and TSLP, is synthesized and secreted by airway epithelial cells in response to various environmental stimuli and / or due to cell damage [13, 16]. The latter induce inflammation of airways by Th2-type and cause remodeling and pathological changes in airways wall. This fact indicates a key role of bronchial epithelial cells in the histophysiology of allergic inflammation [3, 15]. Thus, the respiratory epithelium is not just a structural barrier, but also an "active participant" in allergic airways inflammation [9]. At the same time, a few studies investigated allergic inflammation in the chronobiological aspect is insignificant [19]. Most of the scientific works with focus on the airway epithelium in allergic inflammation, are immunological studies [5, 7, 9, 18]. All the above indicates the need to clarify this topical problem from a morphological point of view in the dynamics of experimental allergic inflammation.

The aim of this work is to study morphometric changes in the cellular composition of guinea pigs distal airways 
epithelium in the dynamics of experimental ovalbumininduced allergic inflammation.

\section{Materials and methods}

The object of the experimental study was lung, removed from 48 sexually mature male guinea pigs weighing 450$600 \mathrm{~g}$, kept in standard conditions of the vivarium of the Zaporizhzhya State Medical University. All manipulations were carried out in compliance with the basic principles of working with experimental animals in accordance with the provisions of the European Convention for the Protection of Vertebrate Animals used for Experimental and Other Scientific Purposes (Strasbourg, 1986), the General Ethical Principles for Animal Experiments adopted by the First National Congress on Bioethics (Kyiv, 2001), the Law of Ukraine "On the protection of animals from cruelty" (from 21.02.2006).

Allergic airway inflammation induced by subcutaneous sensitization and followed challenging by intranasal inhalation with ovalbumin (OVA) (Sigma Aldrich, USA). Guinea pigs were actively sensitized by subcutaneous injections into the interscapular region of ovalbumin $(0.5$ $\mathrm{mg} / \mathrm{mL})$ with alum $(10 \mathrm{mg} / \mathrm{mL}$ in saline) as an adjuvant (AlumVax Hydroxide vaccine adjuvant, OZ Biosciences France) on days 0,7 and 14 . From 21 to 28 days of the experiment, guinea pigs were challenged for $15 \mathrm{~min}$ with inhalation of either OVA ( $10 \mathrm{mg} / \mathrm{mL}$ in saline) via a nebulizer (Little Doctor International, Singapore, LD-211C) coupled to a plastic box. We divided the animals into 6 groups ( 8 animals in each group). The first four groups are animals sensitized and challenged OVA, withdrawn from the experiment, respectively, on the 23rd, 30th, 36th and 44th days after its start; 5 - control group, received injections and challenged with saline only; 6 - intact group. For the purpose of rational presentation of the obtained data and their interpretation, we conditionally distinguish the early (23rd, 30th days of the experiment) and late (36th and 44th days after the start of the experiment) periods of the development of allergic inflammatory process in lung.

The animals were withdrawn from the experiment by an overdose of thiopental anesthesia (50 mg/kg) according to the established terms (23rd, 30th, 36th and 44th days of the experiment). Histological sections stained by hematoxylin-eosin. The average number of epithelial cells of small bronchi and terminal bronchioles was determined: basal epithelium cells, ciliated cells, goblet cells and exocrine bronchiolar cells per unit area of $10000 \mu \mathrm{m}^{2}$.

The research results processed by modern statistical methods of analysis on a personal computer using the standard software package Microsoft Office 2010 (Microsoft Excel) and STATISTICA $\AA$ for Windows 6.0 (StatSoft Inc., USA, license 46 No. AXXR712D833214FAN5). We use the Shapiro-Wilk test and the Kolmogorov-Smirnov test of consistency testing the hypothesis about the normal distribution of the studied parameters. We use the Kolmogorov-Smirnov homogeneity criterion testing the hypothesis that two independent samples belong to the same distribution law. The mean (M) and standard deviation $( \pm m)$ assessed. The statistical significance of intergroup differences according to the data obtained was established using the parametric Student's t-test $\left(p^{*}\right)$ and the nonparametric U-Whitney-Mann test $\left(p^{* *}\right)$. Differences between the compared values at the level of $95 \%(p<0.05)$ were considered statistically significant.

\section{Results}

Histological analysis revealed thickening of bronchial wall and terminal bronchioles due to edema of the respiratory mucosal layer and hypertrophy of smooth muscle cells of guinea pigs sensitized with ovalbumin compared to the intact and control groups (Fig. 1). The degree of manifestation of inflammatory changes increases as the caliber of the bronchi decreases, reaching its maximum in the terminal bronchioles (Fig. 1d). We observed, accumulation of mucus, desquameted epithelial cells with impurities of lymphocytes, neutrophils, eosinophils in airways lumen (Fig. 1b, 1d). In the composition of terminal bronchioles, especially in the places of their transition to respiratory bronchioles, we observed the presence of neuroepithelial bodies, consisted of parallel located, lowprismatic non-ciliated cells, contacted with the basal lamina and airways lumen (Fig. 1c).

There was no statistically significant difference between the average number of epithelial cells of the respiratory mucosal layer of bronchioles in animals of intact and control groups $\left(p^{\star / * *}>0.05\right)$, indicated that the experimental procedure does not affect changes in morphometric parameters of bronchiolar epithelium. There is a tendency to the thinning of bronchiolar epithelium after sensitization and inhalation with ovalbumin in the early period of development of allergic inflammation.

In animals of the 1st experimental group the average number of basal epithelium cells was $7.121 \pm 0.142$ in the field of view, which is statistically significantly less by 1.5 times $\left(p^{*} /{ }^{*}<0.01\right)$ in comparison with the control group. A statistically significant reduction in the average number of basal epithelium cells, compared to the control group, we also observed in animals of the 2nd experimental group $7,501 \pm 0,184$ in the field of view, which is by 1.4 times $\left(\mathrm{p}^{* / *}<0.05\right)$ less than the same indicator in the control group (Table 1). During the late period of the development of allergic inflammation, we observed a statistically significant elevation in the average number of basal epithelium cells of bronchioles in animals of the $3 \mathrm{rd}$ experimental group compared to the previous experimental group $(9,752 \pm 0,133$ in the field of view), which is by 1.3 times more $\left(p^{* *}<0.05\right)$ than the same indicator of the 2 nd experimental group, shown a tendency towards a gradual normalization of this indicator. On the 44th day of observation, the average number of basal epithelium cells in bronchioles is $9,882 \pm 0,101$ in the field of view, which is statistically significantly more than the same indicator in 

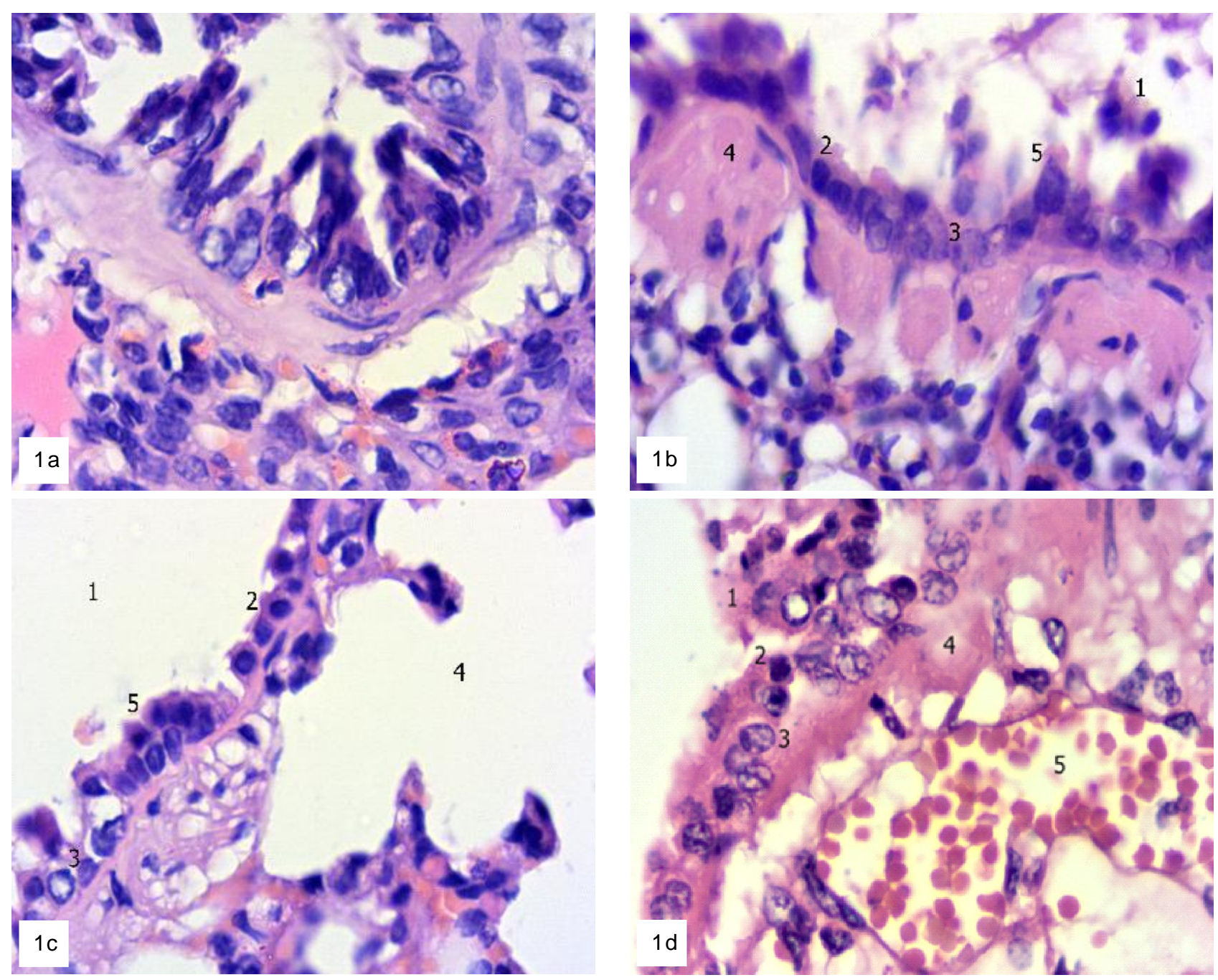

Fig. 1. Microscopic changes of the wall of the small bronchi and terminal bronchioles of guinea pigs after sensitization with ovalbumin at $23(1 \mathrm{~d}), 30(1 \mathrm{~b})$ days after the start of the experiment compared with the control group (1a, 1c). 1a - small bronchus. 1b - small bronchus: 1 - desquamation of the epithelium into the lumen of the bronchus; 2 - the main epitheliocyte; 3 - bronchiolar exocrinocyte; 4 - uneven thickening of the muscular membrane; 5 - ciliated epitheliocyte. 1c terminal bronchiole: 1 - lumen; 2 - the main epitheliocyte; 3 bronchiolar exocrinocyte; 4 - cellular duct; 5 - neuroepithelial body. $1 \mathrm{~d}$ - terminal bronchiole: 1 - desquamation of the epithelium into the lumen; 2 - the main epitheliocyte; 3 - bronchiolar exocrinocyte; 4 - edema and uneven thickening of the muscular membrane; 5 - venule plethora. Hematoxylin-eosin. x1000.

the 2nd experimental group $\left(\mathrm{p}^{* / *}<0.05\right)$. We observed a statistically significant elevation in the average number of undifferentiated epithelial cells in the epithelium of terminal bronchioles in the early period of the development of allergic inflammation in animals of the 2 nd experimental group $9,621 \pm 0,091$ in the field of view, which is twice as much as in the control group. In the late period of the development of allergic inflammation on the 36th day of observation, the average number of undifferentiated epithelial cells of terminal bronchioles was $6,501 \pm 0,172$ in the field of view, which is statistically significantly less by 1.5 times $\left(p^{*} / * *<0.01\right)$ compared to the previous observation period (Table 1 ).

Ciliated cells normally predominate among other cells of the epithelial differon in bronchioles. They have a lowprismatic shape, the narrowed basal part contacted with the basal lamina, the dilated apical part covered by cilia, contacted with the bronchial lumen. There are no ciliated cells in the epithelium of terminal bronchioles of guinea pigs. There was no statistically significant difference between the average number of ciliated cells of bronchioles in animals of intact and control groups $\left(\mathrm{p}^{* / *}>0.05\right)$. Sensitization and inhalation with ovalbumin led to a statistically significant reduction in the number of ciliated cells during the early period of development of ovalbumininduced allergic airways inflammation. On the 23rd day in the 1st experimental group, the average number of ciliated cells of bronchioles of guinea pigs was $9,752 \pm 0,112$ in the field of view, which is by 1.6 times statistically significantly less $\left(p^{*} / * * 0.001\right)$, compared to the control group. In animals of the 2 nd experimental group, the average number 
Changes in the cellular composition of guinea pig's distal airways epithelium in the dynamics of experimental ...

Table 1. Morphometric parameters of epithelium of bronchioles and terminal bronchioles of guinea pigs after sensitization with ovalbumin.

\begin{tabular}{|c|c|c|c|c|c|c|c|c|}
\hline Group & & $I$ & & II & & III & & IV \\
\hline \multirow{2}{*}{1} & A & $7.121 \pm 0.142^{* / * *}$ & A & $9.752 \pm 0.112^{* / *}$ & A & $4.501 \pm 0.093^{* / * *}$ & A & $3.622 \pm 0.131^{* / * *}$ \\
\hline & B & $4.622 \pm 0.161$ & $\mathrm{~B}$ & - & B & $11.75 \pm 0.26^{\star / \star \star}$ & $\mathrm{B}$ & - \\
\hline \multirow{2}{*}{2} & $A$ & $7.501 \pm 0.184^{* / * *}$ & $A$ & $10.12 \pm 0.27^{\star / \star \star}$ & $A$ & $8.122 \pm 0.101$ & $A$ & $4.251 \pm 0.113^{* / * *}$ \\
\hline & $\mathrm{B}$ & $9.621 \pm 0.091^{* / * *}$ & $\mathrm{~B}$ & - & $\mathrm{B}$ & $11.88 \pm 0.25^{\star / * *}$ & $\mathrm{~B}$ & - \\
\hline \multirow{2}{*}{3} & A & $9.752 \pm 0.133$ & A & $12.62 \pm 0.14^{\star / * *}$ & A & $9.001 \pm 0.201$ & A & $3.251 \pm 0.072^{\star / * \star}$ \\
\hline & B & $6.501 \pm 0.172$ & $\mathrm{~B}$ & - & B & $12.01 \pm 0.27^{\star / * *}$ & $\mathrm{~B}$ & - \\
\hline \multirow{2}{*}{4} & A & $9.882 \pm 0.101$ & A & $15.38 \pm 0.14$ & A & $7.253 \pm 0.112$ & A & $1.623 \pm 0.051$ \\
\hline & $B$ & $5.382 \pm 0.161$ & $\mathrm{~B}$ & - & $\mathrm{B}$ & $17.75 \pm 0.28$ & $\mathrm{~B}$ & - \\
\hline \multirow{2}{*}{5} & A & $10.38 \pm 0.10$ & A & $15.25 \pm 0.16$ & A & $7.501 \pm 0.103$ & $A$ & $1.622 \pm 0.071$ \\
\hline & $\mathrm{B}$ & $4.751 \pm 0.082$ & $\mathrm{~B}$ & - & $\mathrm{B}$ & $18.52 \pm 0.24$ & $\mathrm{~B}$ & - \\
\hline \multirow{2}{*}{6} & $A$ & $10.25 \pm 0.17$ & $A$ & $15.75 \pm 0.27$ & $A$ & $7.252 \pm 0.103$ & $A$ & $1.881 \pm 0.061$ \\
\hline & B & $4.621 \pm 0.101$ & B & - & B & $18.88 \pm 0.20$ & B & - \\
\hline
\end{tabular}

Notes: ${ }^{*}-p<0.05$ (Student's t-test); ${ }^{* *}-p<0.05$ (Whitney-Mann U-test) compared to the control group (M $\left.\pm m, n=8\right)$. A - bronchiole; B terminal bronchiole. I - the average number of basal/undifferentiated epithelium cells $/ 10000 \mu \mathrm{m}^{2}$; II - the average number of ciliated cells/ $10000 \mu \mathrm{m}^{2}$; III - the average number of exocrine bronchiolar cells $/ 10000 \mu \mathrm{m}^{2}$; IV - the average number of goblet cells $/ 10000 \mu \mathrm{m}^{2}$.

of ciliated cells of bronchioles was $10.12 \pm 0.27$ in the field of view, which is by 1.5 times $\left(p^{* / *}<0.01\right)$ less than in the control group. In animals of the 3rd experimental group, the average number of ciliated cells was $12.62 \pm 0.14$ in the field of view, which is by 1.2 times $\left(p^{* / *}<0.05\right)$ less than in the control group, but statistically significantly more $\left(p^{* *}<0.05\right)$ compared to the previous group. On the 44 th day of observation, the average number of ciliated cells was $15.38 \pm 0.14$ in the field of view, which is by 1.2 times statistically significantly more $\left(\mathrm{p}^{* / *}<0.05\right)$, compared to the same indicator in the 3rd experimental group.

Exocrine bronchiolar cells occupied mainly terminal and respiratory bronchioles, have a cubic or pyramidal shape, a light nucleus, their apical part protruding into the lumen of terminale bronchiole. A statistically significant decrease in the average number of exocrine bronchiolar cells of bronchioles, compared to the control group, is observed only in the early period of development of allergic inflammation in animals of the 1st experimental group $4,501 \pm 0,09$ in the field of view, which is by 1.6 times $\left(p^{*} /\right.$ ${ }^{* *}<0.01$ ) less than the same indicator in the control group. During the following periods of observation, there was a gradual elevation of this indicator. In animals of the 2 nd experimental group, the average number of exocrine bronchiolar cells in bronchioles was $8,122 \pm 0,101$ in the field of view, which is by 1.8 times $\left(p^{* / *}<0.001\right)$ more than the same indicator of the previous observation period. We also observed a statistically significant decrease in the average number of exocrine bronchiolar cells in terminal bronchioles compared to the control group. In the early period of the development of allergic inflammation in animals of the 1st experimental group, the average number of exocrine bronchiolar cells in terminal bronchioles was $11.75 \pm 0.26$ in the field of view, which is by 1.6 times $\left(p^{*} /\right.$ $\left.{ }^{* *}<0.01\right)$ less than the same indicator in the control group.
By the end of the experiment, the average number of exocrine bronchiolar cells was restored to the control indicator. So, in animals of the 4th experimental group, the average number of exocrine bronchiolar cells of terminal bronchioles was $17.75 \pm 0.28$ in the field of view, which is by 1.5 times $\left(p^{* / *}<0.05\right)$ more than the same indicator of previous group.

We have shown the most significant morphometric changes relative to goblet cells of respiratory mucosal layer of bronchioles of guinea pigs after sensitization and aeroallergization with ovalbumin. In animals of the 1 st experimental group, the average number of goblet cells was $3,622 \pm 0,131$ in the field of view, which is statistically significantly more by 2.2 times $\left(p^{* / * *}<0.05\right)$ than the same indicator in the control group. A statistically significant elevation in the average number of goblet cells of guinea pigs' bronchioles, compared to the control group, is also observed in animals of the 2nd experimental group $4,251 \pm 0,113$ in the field of view, which is by 2.6 times $\left(p^{\star} /\right.$ $\left.{ }^{* *}<0.01\right)$ more than the same indicator in the control group. There is a tendency towards a decrease in the number of goblet cells of respiratory mucosal layer in bronchioles and the return of this indicator to normal parameters by the end of the experiment during the late period of the development of allergic inflammation. A statistically significant increase in the average number of goblet cells in bronchioles in comparison with the control group in animals of the 3rd experimental group is $3,251 \pm 0,072$ in the field of view, which is by 2 times more $\left(p^{\star / *}<0.01\right)$ than the same indicator in the control group. On the 44th day of observation, the average number of goblet cells in bronchioles was $1,623 \pm 0,051$ in the field of view, which is statistically significantly less $\left(\mathrm{p}^{*} / * *<0.01\right)$ compared to the 3 rd experimental group. There are no goblet cells in guinea pigs' terminal bronchioles. 


\section{Discussion}

Thus, this study has reported the regularity of changes in the cellular composition of the epithelium in bronchioles and terminal bronchioles in the dynamics of allergic inflammation. We have noted the most significant reactive morphometric changes on the 23rd and 30th days of observation detected in the form of the decrease in the number of basal and ciliated cells and the magnification in the average number of goblet cells in the epithelium of bronchioles, as well as a decrease in the average number of exocrine bronchiolar cells in terminal bronchioles. In our opinion, this is due to alterative phenomena in the early period of development of allergic inflammation of the airways, namely, desquamation of the epithelial layer. Hypertrophy and hyperplasia of goblet cells is a morphological confirmation of the development of bronchial hyperreactivity as a result of the action of an allergen, primarily associated with the action of CGRP (calcitonin gene-related peptide) of respiratory endocrine cells - proinflammatory cells. CGRP activates type 2 innate lymphoid cells. These results were in agreement with previous studies [4, 12, 14]. Another secretory product of the neurotransmitter, $y$-aminobutyric acid GABA, interacts with $\mathrm{IL}-13$ to activate the secretion of goblet cells mucus. In this case, innate lymphoid cells type II release a large amount of type 2 cytokines after cytokine stimulation of epithelial cells of respiratory mucosal layer (IL-25, IL-33, TSLP) [16, 17]. Recent studies have shown that these cells in lung of small mammals are the main source of IL-5 and IL-13; therefore, it is logical to assume that they are directly involved in the induction of allergic inflammatory process $[13,16$, 20]. IL-5 of innate lymphoid cells type II activates eosinophils, promoting the elevation of their number in the connective tissue of lung. The latter, in turn, increase the secretion of mucus by goblet cells and stimulate hypertrophy and contraction of smooth muscle cells. IL-13 of innate lymphoid cells type II directly affects goblet cells, stimulating their hyperplasia and increased mucus secretion $[6,8]$. The decrease in the number of exocrine bronchiolar cells in the epithelium of distal airways of guinea

\section{References}

[1] Ahmed, Zaky, E., Fouda, E.M., \& Kamel, T.B. (2018). Assessment of small airway impairment in relation to pediatric asthma control and bronchial hyper-responsiveness. QJM: An International Journal of Medicine, 111(1). https://doi.org/10.1093/qjmed/ hcy200.132

[2] Banno, A., Reddy, Aravind, T., Lakshmi, Sowmya, P., \& Reddy, Raju C. (2020). Bidirectional interaction of airway epithelial remodeling and inflammation in asthma. Clinical Science, 134(9), 1063-1079. https://doi.org/10.1042/cs20191309

[3] Barrios, J., Kho, A.T., Aven, L., Mitchel, J.A., Park, J.-A., Randell, S.H. ... Ai, X. (2019). Pulmonary Neuroendocrine Cells Secrete Y-Aminobutyric Acid to Induce Goblet Cell Hyperplasia in Primate Models. American Journal of Respiratory Cell and Molecular Biology, 60(6), 687-694. https://doi.org/10.1165/ rcmb.2018-0179oc

[4] Bartemes, K.R., \& Kita, H. (2012). Dynamic role of epithelium- pigs is a confirmation of the alteration of airways due to allergic inflammation. A similar trend of morphological changes in the bronchioles is suggested by other scientists [3, 12, 13, 17]. Exocrine bronchiolar cells perform specialized functions necessary to protect the body in a normal state, but retain the ability to proliferate in response to injury. We consider this population of cells to be facultative progenitor cells of distal airways and the respiratory part of lung, which also was reported by previous scientific data [7]. It is bronchiolar exocrinocytes that provide epithelial renewal after damage to ciliated cells and other cellular phenotypes that we have shown during the late period of allergic inflammation. Exocrine bronchiolar cells in lung also have anti-inflammatory immunomodulatory effect, produce surfactant components SP-A, SP-B, SP-D. These hydrophobic proteins prevent bronchiole wall adhesion and airway collapse at this level. The secretory protein of exocrine bronchiolar cells CC16 regulates the immune response in lung to various allergens. Thus, by influencing the activity of certain cellular phenotypes of the airway epithelium, it is possible to reduce the intensity of allergic inflammatory process, which opens new perspectives in the treatment of bronchial asthma [11].

We are going to study ultramicroscopic changes in epithelial cells of bronchioles and terminal bronchioles of guinea pigs with allergic inflammation.

\section{Conclusions}

1. It was found that sensitization and allergization with ovalbumin in experimental animals caused statistically significant morphological changes in the cellular composition of bronchioles and terminal bronchioles: alterative - in the early period, adaptive - in the late period of allergic inflammation, demonstrated the main morphological manifestations of allergic inflammation.

2. Confirmation of the development of hyperreactivity of bronchioles and terminal bronchioles in experimental animals is hypertrophy and hyperplasia of goblet cells, most pronounced during the early period of development of allergic inflammation.

derived cytokines in asthma. Clinical Immunology, 143(3), 222-235. https://doi.org/10.1016/j.clim.2012.03.001

[5] Bonser, L.R., \& Erle, D.J. (2019). The airway epithelium in asthma. Advances in Immunology, 142, 1-34. https://doi.org/10.1016/ bs.ai.2019.05.001

[6] Branchfield, K., Nantie, L., Verheyden, J. M., Sui, P., Wienhold, M. D., \& Sun, X. (2016). Pulmonary neuroendocrine cells function as airway sensors to control lung immune response. Science, 351(6274), 707-710. https://doi.org/10.1126/ science.aad7969

[7] Davis, J. D., \& Wypych, T. P. (2021). Cellular and functional heterogeneity of the airway epithelium. Mucosal Immunology, 14(5), 978-990. https://doi.org/10.1038/s41385-020-00370-7

[8] Denney, L., Byrne, A.J., Shea, T.J., Buckley, J.S., Pease, J.E., Herledan, G.M.F. ... Lloyd, C.M. (2015). Pulmonary Epithelial Cell-Derived Cytokine TGF-B1 Is a Critical Cofactor for 
Enhanced Innate Lymphoid Cell Function. Immunity, 43(5), 945958. https://doi.org/10.1016/j.immuni.2015.10.012

[9] Frey, A., Lunding, L.P., Ehlers, J.C., Weckmann, M., Zissler, U.M., \& Wegmann, M. (2020). More Than Just a Barrier: The Immune Functions of the Airway Epithelium in Asthma Pathogenesis. Frontiers in Immunology, 11, 761. https:// doi.org/10.3389/fimmu.2020.00761

[10] Gon, Y., \& Hashimoto, S. (2018). Role of airway epithelial barrier dysfunction in pathogenesis of asthma. Allergology International, 67(1), 12-17. https://doi.org/10.1016/ j.alit.2017.08.011

[11] Gras, D., Chanez, P., Vachier, I., Petit, A., \& Bourdin, A. (2013). Bronchial epithelium as a target for innovative treatments in asthma. Pharmacology \& Therapeutics, 140(3), 290-305. https://doi.org/10.1016/j.pharmthera.2013.07.008

[12] Han, Y., Chen, L., Liu, H., Jin, Z., Wu, Y., Wu, Y. ... Yan, F. (2020). Airway Epithelial cGAS Is Critical for Induction of Experimental Allergic Airway Inflammation. The Journal of Immunology, 204(6), 1437-1447. https://doi.org/10.4049/ jimmunol.1900869

[13] Holgate, S.T. (2008). The Airway Epithelium is Central to the Pathogenesis of Asthma. Allergology International, 57(1), 110. https://doi.org/10.2332/allergolint.r-07-154

[14] Lambrecht, B.N., \& Hammad, H. (2014). The immunology of asthma. Nature Immunology, 16(1), 45-56. https://doi.org/ $10.1038 /$ ni.3049

[15] Li, S., Koziol-White, C., Jude, J., Jiang, M., Zhao, H., Cao, G. ... Morrisey, E. E. (2016). Epithelium-generated neuropeptide $Y$ induces smooth muscle contraction to promote airway hyperresponsiveness. Journal of Clinical Investigation, 126(5), 1978-1982. https://doi.org/10.1172/jci81389

[16] Li, Y.-L., Li, H.-J., Ji, F., Zhang, X., Wang, R., Hao, J.-Q. ... Dong, L. (2010). Thymic Stromal Lymphopoietin Promotes Lung Inflammation Through Activation of Dendritic Cells. Journal of Asthma, 47(2), 117-123. https://doi.org/10.3109/ 02770900903483816

[17] Mitchel, J.A., Antoniak, S., Lee, J.-H., Kim, S.-H., McGill, M., Kasahara, D.I. .. Park, J.-A. (2016). IL-13 Augments Compressive Stress-Induced Tissue Factor Expression in Human Airway Epithelial Cells. American Journal of Respiratory Cell and Molecular Biology, 54(4), 524-531. https:/ /doi.org/10.1165/rcmb.2015-0252oc

[18] Moro, K., Kabata, H., Tanabe, M., Koga, S., Takeno, N., Mochizuki, M. ... Koyasu, S. (2015). Interferon and IL-27 antagonize the function of group 2 innate lymphoid cells and type 2 innate immune responses. Nature Immunology, 17(1), 76-86. https:/ /doi.org/10.1038/ni.3309

[19] Popko, S.S., \& Evtushenko, V.M. (2020). Morphometric characteristics of distal airways of guinea pigs sensitized with ovalbumin. Reports of Morphology, 26(4), 42-47. https:/ /doi.org/10.31393/morphology-journal-2020-26(4)-07

[20] Popko, S.S., Evtushenko, V.M., \& Syrtsov, V.K. (2020). Influence of pulmonary neuroendocrine cells on lung homeostasis. Zaporozhye Medical Journal, 22(4), 568-575. https://doi.org/ $10.14739 / 2310-1210.4 .208411$

\section{ЗМІНИ КЛІТИННОГО СКЛАДУ ЕПІТЕЛІЮ ДИСТАЛЬНИХ ВІДДІЛІВ ДИХАЛЬНИХ ШЛЯХІВ МОРСЬКИХ СВИНОК В ДИНАМІЦІ ЕКСПЕРИМЕНТАЛЬНОГО ОВАЛЬБУМІН-ІНДУКОВАНОГО АЛЕРГІЧНОГО ЗАПАЛЕННЯ \\ Попко С.C.}

Проблема вивчення процесів перебудови епітеліального шару дихальних шляхів людини і тварин адаптаційного характеру при дії на організм різноманітних чинників як і раніше залишається предметом наукових дискусій. Мета роботи - дослідити морфометричні зміни клітинного складу епітелію дистальних відділів дихальних шляхів морських свинок в динаміці експериментального овальбумін-індукованого алергічного запалення. За допомогою гістологічного, морфометричного та статистичного методів вивчили легені 48 самців морської свинки в умовах експериментального овальбумін-індукованого алергічного запалення, яке моделювали шляхом підшкірної сенсибілізації та наступної інтраназальної інгаляції овальбуміном. Визначали середню кількість епітеліоцитів дихальної слизової оболонки малих бронхів і термінальних бронхіол: основних, війчастих епітеліоцитів, келихоподібних та бронхіолярних екзокриноцитів на одиницю площі 10000 мкм². Найбільш значимі реактивні морфометричні зміни встановлено на 23 і 30 добу спостереження у вигляді зменшення кількості основних (у 1,5 рази порівняно з контролем, $\left.p^{* / * *}<0,01\right)$ та війчастих епітеліоцитів (в 1,6 рази порівняно з контролем, $p^{* / * *<0,001) ~ i ~ з р о с т а н н я ~}$ середньої кількості келихоподібних екзокриноцитів (в 2,6 рази порівняно з контролем, $\left.p^{* * *}<0,01\right)$ у складі епітелію малих бронхів, а також зменшення середньої кількості бронхіолярних екзокриноцитів (в 1,6 рази порівняно з контролем, $p^{* / * * 0,01)}$ у складі термінальних бронхіол, що є морфологічним підтвердженням розвитку бронхіальної гіперреактивності у результаті дії алергена. Таким чином, сенсибілізація та алергізація овальбуміном викликають статистично значимі морфологічні зміни клітинного складу малих бронхів і термінальних бронхіол альтеративного характеру в ранньому періоді та адаптаційного - в пізньому періоді алергічного запалення, що відповідають основним морфологічним проявам алергічного запалення.

Ключові слова: епітелій, дихальні шляхи, алергічне запалення, овальбумін, морська свинка. 